medRxiv preprint doi: https://doi.org/10.1101/2021.08.19.21262273; this version posted August 25, 2021. The copyright holder for this preprint (which was not certified by peer review) is the author/funder, who has granted medRxiv a license to display the preprint in perpetuity.

It is made available under a CC-BY 4.0 International license.

\title{
Associations between gestational weight gain adequacy and neonatal outcomes in Tanzania
}

Nandita Perumal ${ }^{1}$, Dongqing Wang ${ }^{1}$, Anne Marie Darling ${ }^{1}$, Molin Wang ${ }^{2,3}$, Enju Liu ${ }^{4}$, Willy Urassa $^{5}$, Andrea Pembe ${ }^{6}$, Wafaie W. Fawzi ${ }^{1,2,7}$

${ }^{1}$ Department of Global Health and Population, Harvard T.H. Chan School of Public Health, Harvard University, Boston, Massachusetts, United States of America

${ }^{2}$ Department of Epidemiology, Harvard T.H. Chan School of Public Health, Harvard University, Boston, Massachusetts, United States of America

${ }^{3}$ Department of Biostatistics, Harvard T.H. Chan School of Public Health, Harvard University, Boston, Massachusetts, United States of America

${ }^{4}$ Institutional Centers for Clinical and Translational Research, Boston Children's Hospital, Boston, Massachusetts, United States of America

${ }^{5}$ Department of Microbiology and Immunology, Muhimbili University of Health and Allied Sciences, Dar es Salaam, Tanzania.

${ }^{6}$ Department of Obstetrics and Gynaecology, Muhimbili University of Health and Allied Sciences, Dar es Salaam, Tanzania.

${ }^{7}$ Department of Nutrition, Harvard T.H. Chan School of Public Health, Harvard University, Boston, Massachusetts, United States of America

Short Title: Gestational weight gain and neonatal outcomes

Corresponding Author

Nandita Perumal, $\mathrm{PhD}$

Department of Global Health and Population

Harvard TH Chan School of Public Health

90 Smith Street, $3^{\text {rd }}$ Floor

Boston USA 02215

Phone: 6174329431

Email: nperumal@hsph.harvard.edu

\section{Number of Tables: 3}

\section{Number of Figures: 2}

Keywords: gestational weight gain, birth outcomes, low- and middle-income countries, newborn 


\section{Abstract}

2 Introduction: Gestational weight gain $(\mathrm{GWG})$ is associated with fetal and newborn health;

3 however, data from sub-Saharan Africa are limited. Methods: We used data from a prenatal

4 micronutrient supplementation trial among a cohort of HIV-negative pregnant women in Dar es

5 Salaam, Tanzania to estimate the relationships between GWG and newborn outcomes. GWG

6 adequacy was defined as the ratio of the total observed weight gain over the recommended

7 weight gain based on the Institute of Medicine body mass index (BMI)-specific guidelines.

8 Newborn outcomes assessed were: stillbirth, perinatal death, preterm birth, low birthweight,

9 macrosomia, small-for-gestational age (SGA), large-for-gestational age (LGA), stunting at birth, and microcephaly. Modified Poisson regressions with robust standard error were used to estimate

11 the relative risk of newborn outcomes as a function of GWG adequacy. Results: Of 7561 women

12 included in this study, 51\% had severely inadequate $(<70 \%)$ or inadequate GWG $(70-90 \%), 31 \%$

13 had adequate GWG (90-125\%), and $18 \%$ had excessive GWG ( $\geq 125 \%)$. Compared to adequate

14 GWG, severely inadequate GWG was associated with a higher risk of low birthweight, SGA,

15 stunting at birth, and microcephaly; whereas excessive GWG was associated with a higher risk

16 of LGA and macrosomia. Conclusion: Interventions to support optimal gestational weight gain

17 are needed and are likely to improve newborn outcomes. 
medRxiv preprint doi: https://doi.org/10.1101/2021.08.19.21262273; this version posted August 25, 2021. The copyright holder for this preprint (which was not certified by peer review) is the author/funder, who has granted medRxiv a license to display the preprint in perpetuity.

It is made available under a CC-BY 4.0 International license .

\section{INTRODUCTION}

19 Weight gain during pregnancy is an important predictor of maternal pregnancy outcomes and newborn health.[1] The 2009 Institute of Medicine (IOM) guidelines provide specific

21 recommendations for total gestational weight gain (GWG) during pregnancy according to a

22 woman's pre-pregnancy body-mass-index (BMI).[1] Inadequate or excessive GWG has been

23 associated with a wide range of adverse maternal and neonatal health outcomes.[1,2] For

24 example, inadequate GWG has been associated with a higher risk of low birthweight, small-for-

25 gestational age (SGA), and preterm birth, whereas excessive GWG has been associated with a

26 higher risk of cesarean delivery, large-for-gestational age (LGA), and macrosomia.[1-3] Adverse

27 birth outcomes in turn are associated with an increased risk of mortality,[4] suboptimal

28 growth,[5] lower neurodevelopment[6] and schooling achievement,[7] and adverse

29 cardiometabolic outcomes later in life. Gaining weight during pregnancy within the

recommended guidelines is therefore important to minimize the risk of adverse birth outcomes.

The IOM recommendations for GWG, however, are based on data from high-income settings and do not include evidence from any studies examining the relationship between GWG and neonatal outcomes in low-income settings. In high-income countries, the prevalence of adverse birth outcomes is low ( 4-5\%) and maternal overweight and excessive GWG are a larger concern during antenatal care.[3,8-10] In contrast, $25 \%$ of all live births globally that are

37 estimated to be low birthweight or preterm occur in countries in sub-Saharan Africa.[8,9] In

38 addition, evidence from population-representative surveys in 67 low and middle-income 
medRxiv preprint doi: https://doi.org/10.1101/2021.08.19.21262273; this version posted August 25, 2021. The copyright holder for this preprint (which was not certified by peer review) is the author/funder, who has granted medRxiv a license to display the preprint in perpetuity.

It is made available under a CC-BY 4.0 International license .

total GWG of $6.6 \mathrm{~kg}$ (95\% uncertainty intervals: $3.4,9.9)$, which is less than $60 \%$ of the minimum recommended GWG for normal weight women based on the IOM guidelines.[11]

A recent systematic review and meta-analysis of a relatively few studies conducted in subSaharan Africa suggests that inadequate and excessive GWG are similarly associated with low birthweight and macrosomia, respectively, as observed in high-income settings. However, most of the studies included in the meta-analysis were cross-sectional or retrospective cohort study design, were based on a sample size of $<500$ participants, were noted to have poor control of confounding variables, and examined relationships primarily with newborn weight.[12] In this study, we use data from a large, prospective cohort of pregnant women in Dar es Salaam, Tanzania, to examine the relationships between GWG during pregnancy and a wide range of neonatal outcomes. In addition, we assessed whether associations between maternal GWG and neonatal outcomes were modified by maternal age and nutritional status, as assessed by maternal pre-pregnancy BMI.

\section{METHODS}

\section{Study design and population}

We used secondary data from participants enrolled in a double-blind randomized controlled trial of daily prenatal multiple micronutrient supplementation during pregnancy conducted between 2001 to 2005 in Dar es Salaam, Tanzania. The trial procedures and primary findings are published in detail elsewhere.[13] Briefly, 8428 pregnant women between 12 to 28 weeks gestation were randomized to receive either a daily multiple micronutrient supplement (MMS) or 
63 placebo during pregnancy to investigate the effects on perinatal outcomes, including low

64 birthweight (<2500 grams), preterm birth, and fetal death. In line with standard of care in

65 Tanzania, all participants received daily supplements of $0.25 \mathrm{mg}$ folic acid, $60 \mathrm{mg}$ of ferrous

66 sulfate, and sulfadoxine-pyrimethamine for malaria prophylaxis.

67

68 Participants were screened and recruited from antenatal care clinics in nine health centers in Dar es Salaam, Tanzania, if they met the following eligibility criteria: (i) tested negative for human immunodeficiency virus (HIV) infection, (ii) were between 12 and 27 weeks of gestational age

71 based on date of last menstrual period, (iii) were 18 years of older, and (iv) intended to stay in

72 Dar es Salaam for at least 1 year after delivery. Participants were followed monthly from the

73 time of enrolment until 32 weeks gestational age, after which they were followed every 2 weeks

74 until the $36^{\text {th }}$ week of gestation, and then every week until 6 weeks postpartum. Trained research

75 nurses administered the questionnaires to collect socio-demographic information, detailed

76 medical and obstetric history, and performed clinical examinations at baseline and each follow-

77 up visit. Written informed consent was obtained from all participants enrolled in the trial.

80 Maternal weight was measured at enrollment and at every scheduled follow-up visit. Weight was

81 recorded to the nearest 100 grams with balance scales with women wearing light clothing

82 without shoes. To calculate the observed GWG, we subtracted the women's first trimester weight

83 from the last observed weight prior to delivery. 
Because women were eligible to be in the trial if they were between 12 to 27 weeks of age, we

86

87

88

89

90

91

92

93

94

95

96

97

98

99

100

101

102

103

104

8
did not have first trimester weight for $98 \%$ of the participants. We therefore imputed the first trimester weight for all women at 9 weeks gestation (mid-point of the first trimester), as a proxy of pre-pregnancy weight, using a mixed-effects model with restricted cubic splines with 3 knots using all available maternal weights during the first and second trimesters. The methodology and validation procedures for the imputation have been described in detail elsewhere.[14] We then used the imputed or observed first trimester weight for each participant to as a proxy to assess maternal pre-pregnancy BMI and classified women as being underweight (BMI $<18.5 \mathrm{~kg} / \mathrm{m}^{2}$ ), normal weight (BMI 18.5 to $24.9 \mathrm{~kg} / \mathrm{m}^{2}$ ), overweight (BMI 25 to $29.9 \mathrm{~kg} / \mathrm{m}^{2}$ ) or obese (BMI $\geq 30$ $\mathrm{kg} / \mathrm{m}^{2}$ ) based on the World Health Organization criteria. For participants who were $<20$ years of age at enrolment, we used the World Health Organization BMI-for-age growth references [15] to classify adolescents as underweight (<-2 SD), normal weight (-2 SD to <1 SD), overweight (1 $\mathrm{SD}$ to $<+2 \mathrm{SD})$ or obese $(\geq+2 \mathrm{SD})$

We then used GWG adequacy ratio based on IOM recommendations as the primary exposure of interest. This metric has been previously used in studies of GWG[16] and offers the major advantage of being independent of gestational duration as it is the ratio of absolute maternal weight gain over the recommended weight gain in the same gestational duration, estimated as follows:

$$
\% \text { Adequacy ratio }=\frac{\text { Observed } G W G}{\text { Expected } G W G} \times 100
$$


medRxiv preprint doi: https://doi.org/10.1101/2021.08.19.21262273; this version posted August 25, 2021. The copyright holder for this preprint (which was not certified by peer review) is the author/funder, who has granted medRxiv a license to display the preprint in perpetuity.

It is made available under a CC-BY 4.0 International license .

Where, the recommended weight gain according to IOM guidelines is estimated as follows:

Expected GWG at the last observed weight measure = Expected 1st trimester weight + [(GA at the last weight measure -13.86 weeks $) \times$ BMI specific recommeded rate of GWG in the 2 nd and 3rd trimesters]

(Equation 2)

113 Where the expected weight gain for each participant was the sum of the BMI-specific expected

1141 st trimester weight (at the end of $13^{6 / 7}$ weeks) and the weight gain up to last weight measure

115 based on the BMI-specific expected rate of weight gain in the 2nd and 3rd trimesters (Table 1).

116 The GWG adequacy ratio was derived as a continuous measure and categorized as follows for 117 analysis: severely inadequate $(<70 \%)$; inadequate (70 to $<90 \%)$, adequate (90 to $<125 \%)$, and 118 excessive $(\geq 125 \%)$.

We also used the INTERGROWTH-2 $1^{\text {st }}$ Gestational Weight Gain standards (IG-GWG) to derive

121 standardized indices (z-scores) of GWG for normal weight women.[17] The IG-GWG provide a

122 new reference population for assessing GWG adequacy associated with optimal maternal and

123 perinatal outcomes as these standards are based on a multi-ethnic population of healthy normal

124 weight pregnant women from high-socioeconomic status and with no known risk factors. We

125 derived GWG z-scores for each participant and outlying values, defined as observations with

126 GWG z-score above 6 standard deviations (SD) or below -6 SD, were excluded from analysis. 
medRxiv preprint doi: https://doi.org/10.1101/2021.08.19.21262273; this version posted August 25, 2021. The copyright holder for this preprint (which was not certified by peer review) is the author/funder, who has granted medRxiv a license to display the preprint in perpetuity.

It is made available under a CC-BY 4.0 International license.

127 GWG Z-scores were categorized into four categories for analysis (<-2 SD, -2 SD to <-1 SD, -1

$128 \quad \mathrm{SD}$ to $<1 \mathrm{SD}$, and $\geq 1 \mathrm{SD})$.

\section{Outcome assessment}

131 We assessed several neonatal mortality and anthropometric outcomes. Detailed information on

132 infant status at birth and up to 6 weeks postpartum were collected during scheduled visits.

133 Neonatal mortality outcomes examined were stillbirth, defined as death of the fetus after 28

134 weeks; and perinatal death, defined as death of an infant after 28 weeks gestation and within the 135 first 7 days of life. Trained research midwives measured newborn weight at the time of delivery 136 to the nearest 10 grams using digital scales and newborn length using a length board. We used

137 standard definitions of preterm birth ( $<37$ weeks gestational age), low birthweight $(<2500$

138 grams), and macrosomia (>4000 grams). We used the INTERGROWTH- $21^{\text {st }}$ Newborn Size

139 Standards to derive gestational age- and sex-standardized percentiles/z-scores to classify: small-

140 for-gestational age (SGA; $<10^{\text {th }}$ percentile of birthweight), large-for-gestational age (LGA; $>90^{\text {th }}$

141 percentile for birthweight), stunting at birth (length-for-gestational age z-score <-2SD), and

142 microcephaly (head circumference-for-gestational age z-score <-2SD).

\section{Confounders}

145 We identified several confounders of the associations between GWG adequacy and neonatal

146 outcomes. These included maternal age $(<20,20-24,25-29$, or $\geq 30$ years $)$, education $(0-4,5-7,8$ -

14711 , or $\geq 12$ years), marital status (living alone or with partner), parity (none, 1,2 , or $\geq 3$ ), wealth

148 index, smoking status (yes/no), maternal alcohol consumption (never, $<1$ per week, or $\geq 1$ per

149 week), malaria infection at enrolment (yes/no), and prenatal supplementation group (multiple 
medRxiv preprint doi: https://doi.org/10.1101/2021.08.19.21262273; this version posted August 25, 2021. The copyright holder for this preprint (which was not certified by peer review) is the author/funder, who has granted medRxiv a license to display the preprint in perpetuity.

It is made available under a CC-BY 4.0 International license .

150

151

152

153

154

155

156

157

158

159

160

161

162

163

164

165

166

167

168

micronutrients vs placebo). Wealth index was constructed by a linear index of asset ownership indicators (television, refrigerator, radio, sofa, and fan) based on principal component analysis.[18] We did not adjust for maternal reproductive history as adjusting for these factors has been shown to introduce bias and underestimate the relationships for factors in current pregnancy.[19] We adjusted for maternal pre-pregnancy BMI as a confounder as well, but did not adjust for any factors, such as gestational diabetes or hypertension, that would fall on the causal pathway from GWG to neonatal outcomes (Figure 1).

\section{Statistical analysis}

Analyses were limited to women with singleton pregnancy $(n=156$ women with twins or triplets excluded) and known date of gestational age by last menstrual period. We further excluded weight measures (but not participants) if the weight was taken after 43 weeks gestational age as these were likely to be postpartum weight ( $n=140$ weight measures), and if the values were extreme (defined as $<30 \mathrm{~kg}$ or $>120 \mathrm{~kg} ; \mathrm{n}=7$ weight measures). We used modified Poisson regression with robust standard error to estimate the multivariable adjusted relative risks of neonatal outcomes as a function of GWG adequacy in primary analysis, and GWG z-scores in secondary analysis. Because a participant's last weight measure may be in the second or third trimester, we base inferences regarding total GWG adequacy on participants for whom at least one weight measure in the third trimester was available. We further assessed relationships with 'early' GWG adequacy using the last weight measure in the second trimester. We used two-way interaction terms with GWG adequacy to assess whether relationships between GWG adequacy and neonatal outcomes were modified by maternal pre-pregnancy BMI and maternal age. Due to the small sample size of women classified as having obesity based on their pre-pregnancy BMI 
medRxiv preprint doi: https://doi.org/10.1101/2021.08.19.21262273; this version posted August 25, 2021. The copyright holder for this preprint (which was not certified by peer review) is the author/funder, who has granted medRxiv a license to display the preprint in perpetuity.

It is made available under a CC-BY 4.0 International license .

173 ( $\mathrm{n}=379)$, we combined women with overweight and obese pre-pregnancy BMI classification for

174

175

176

177

178

179

180

181

182

183

184

185

186

187

188

189

190

191

192

193

194

195

interaction analyses. Wald test for interaction was considered statistically significant at two-sided alpha $<0.05$. All analyses were conducted in Stata 16 (College Station, Texas).

\section{RESULTS}

Data from 7561 mother-infant dyad were included in this study. The mean (SD) gestational age of participants at enrolment was 21 (3.4) weeks and at delivery was 39 (3.6), with an average of 4.2 weight measures taken per participant during pregnancy. Most participants were between 2030 years of age, had less than or equal to primary school education, were married, were primiparous, and were normal weight (Table 2). Overall, 25\% of women had either severely inadequate GWG, 26\% had inadequate GWG, 31\% had adequate GWG, and $18 \%$ gained excessive GWG. The prevalence of stillbirths (3.5\%), perinatal death (6.1\%), LBW (6.8\%), macrosomia (2.5\%), and microcephaly (8.5\%) were relatively low; however, SGA (20\%), LGA (13\%), stunting at birth (26\%), and preterm birth (17\%) prevalence were high.

The relationships between GWG adequacy and neonatal outcomes are summarized in Table 3. Compared to adequate GWG, total severely inadequate GWG was associated with a higher risk of LBW (adjusted RR 1.64, 95\% confidence intervals (CI): 1.24, 2.16), SGA (RR 1.81, 95\%CI: $1.53,2.14)$, stunting at birth (RR 1.27, 95\%CI: $1.06,1.52)$, and microcephaly (RR 1.35, 95\%CI: 1.04, 1.74); but a lower risk of LGA (RR 0.69, 95\%CI: 0.56, 0.86) and macrosomia (RR 0.29, 95\%CI: 0.16, 0.54). Total inadequate GWG was also associated with a higher risk of SGA and microcephaly, and a lower risk of LGA (Table 3). Total excessive GWG was positively associated with the risk of stillbirth (RR 1.60, 95\%CI: 1.03, 2.42) and LGA (RR 1.44, 95\%CI: 
medRxiv preprint doi: https://doi.org/10.1101/2021.08.19.21262273; this version posted August 25, 2021. The copyright holder for this preprint (which was not certified by peer review) is the author/funder, who has granted medRxiv a license to display the preprint in perpetuity.

It is made available under a CC-BY 4.0 International license .

$1.14,1.81)$. GWG adequacy in the second trimester was similarly associated with neonatal outcomes, although confidence intervals crossed the null for some associations. Notably, severely inadequate GWG in the second trimester was positively associated with the risk of preterm birth (RR 1.58, 95\%CI: 1.31, 1.91) and excessive GWG in the second trimester was positively associated with the risk of macrosomia (RR 1.98, 95\%CI: 1.27, 3.08) (Table 3).

The relationships between GWG adequacy and neonatal outcomes differed by maternal prepregnancy BMI (Figure 2; Supplemental Tables 1-4). For example, severely inadequate GWG was associated with a substantially higher risk of LBW among underweight women (RR 2.95, 95\%CI: 1.95, 4.48) compared to normal weight women (RR 1.34, 95\%CI: 0.97, 1.87; P-forinteraction $=0.03)($ Supplementary Table 1$)$. Similarly, excessive GWG was associated with a higher risk of stillbirth among underweight women (RR 3.13, 95\%CI: 0.96, 10.2) compared to normal weight women $(\mathrm{RR} 1.73,95 \% \mathrm{CI}$ : 0.95, 3.15; P-for-interaction $=0.04)($ Supplementary Table 1). Among overweight or obese women, severely inadequate and excessive GWG were associated with a higher risk of perinatal death (RR 1.87, 95\%CI: 1.06, 3.30 and RR 1.84, 95\%CI: 1.09, 3.12, respectively); however, these relationships were not statistically significantly different from relationships between GWG adequacy and perinatal death among normal weight women (Supplementary Table 1). We also observed some differences in the relationships between GWG adequacy by maternal age (Supplementary Table 3). Severely inadequate GWG was more strongly associated with the higher risk of stunting at birth (RR 1.39, 95\% CI: 1.03, 1.89 ) and with a lower risk macrosomia (RR 0.45, 95\%CI: $0.13,1.54)$ among women who were >30 years, compared with women 20-29 years of age (stunting: RR 0.95, 95\%CI: 0.72, 1.26; Pfor-interaction $=0.01$; macrosomia: $\mathrm{RR} 0.69,95 \% \mathrm{CI}: 0.27,1.77$; P-for-interaction $=0.03)$. Other 
medRxiv preprint doi: https://doi.org/10.1101/2021.08.19.21262273; this version posted August 25, 2021. The copyright holder for this preprint (which was not certified by peer review) is the author/funder, who has granted medRxiv a license to display the preprint in perpetuity.

It is made available under a CC-BY 4.0 International license.

219

220

221

222

223

224

225

226

227

228

229

230

231

232

233

234

235

236

237

238

239

240

241

relationships between GWG adequacy and neonatal outcomes were not modified by maternal age (Supplementary Tables 3 and 4).

In secondary analyses, we also examined associations between GWG z-scores and neonatal outcomes using IG-GWG standard among normal weight women (Supplementary Table 5).

Relationships between total GWG z-scores and neonatal outcomes were similar to GWG adequacy ratio, with a few exceptions. For example, total GWG z-score $\geq 1 \mathrm{SD}$ was positively associated with the risk of stillbirth (RR 2.51, 95\%CI: 1.26, 4.99) and GWG z-score <-1 SD in the second trimester, but not total, was positively associated with the risk of preterm birth (GWG z-score -2 SD to <-1 SD: RR 1.58, 95\%CI: 1.22, 2.06; GWG z-score <-2 SD: RR 1.51, 95\% CI: 1.01, 2.24) (Supplementary Table 5).

\section{DISCUSSION}

We used secondary data from a large prospective cohort of pregnant women in Dar es Salaam, Tanzania, with multiple weight measures throughout pregnancy, to examine the relationships between GWG adequacy and a wide range of neonatal outcomes. Only a third of women in this study achieved adequate GWG based on IOM recommendations; most women had inadequate or severely inadequate GWG. Overall, inadequate GWG was associated with an increased risk of suboptimal newborn anthropometry, including LBW, SGA, stunting and microcephaly, whereas excessive GWG was positively associated the risk of LGA and macrosomia. Relationships were generally similar with GWG adequacy in the second trimester, except for a higher risk of preterm birth among women with severely inadequate GWG in the second trimester. We also observed a 
medRxiv preprint doi: https://doi.org/10.1101/2021.08.19.21262273; this version posted August 25, 2021. The copyright holder for this preprint (which was not certified by peer review) is the author/funder, who has granted medRxiv a license to display the preprint in perpetuity.

It is made available under a CC-BY 4.0 International license.

242 higher risk of stillbirths associated with excessive GWG among underweight women, compared

243 to normal weight women.

244

245 These findings confirm the importance of GWG adequacy for neonatal health. The association of

246 inadequate GWG with lower birthweight and a higher risk of fetal growth restriction, as

247 measured by SGA, and of excessive GWG with LGA and macrosomia, observed in this study are

248 consistent with previous evidence from high-, middle- and low-income settings.[2,12,20-25]

249 Measures of size at birth have important consequences for long-term child health. Poor fetal

250 growth is associated with an increased risk of mortality, morbidity, and adverse

251 neurodevelopmental consequences.[4,7,26] On the other hand, excessive fetal growth is

252 associated with poor maternal perinatal outcomes (e.g., cesarean section) and childhood

253 obesity.[1,27] The associations of GWG with birth length and head circumference, however,

254 have rarely been evaluated.[28-30] Inadequate GWG in this study was positively associated with

255 the risk of stunting and microcephaly at birth. A longitudinal study of 670 pregnant women in

256 The Gambia similarly found that greater GWG at any level was positively associated with head

257 circumference, but only greater GWG above a threshold of 0.5 SD of conditional weight gain

258 (i.e. greater than expected change in weight in a 3 month interval) was associated with higher

259 birth weight and length; suggesting that better nutrition (as measured by higher GWG) may be

260 prioritized for brain growth over other anthropometric parameters.[21] Secondary data from

261 analysis of a multi-country prenatal nutrition supplementation trial conducted in the Democratic

262 Republic of the Congo, Guatemala, India and Pakistan also found that higher GWG in the first

263 trimester and higher GWG velocity overall were positively associated with birth length and

264 weight.[28] 
medRxiv preprint doi: https://doi.org/10.1101/2021.08.19.21262273; this version posted August 25, 2021. The copyright holder for this preprint (which was not certified by peer review) is the author/funder, who has granted medRxiv a license to display the preprint in perpetuity.

It is made available under a CC-BY 4.0 International license.

266 We also found that inadequate GWG in the second trimester was positively associated with the 267 risk of preterm birth, an association that was also observed among normal weight women when 268 using GWG z-scores based on the INTERGROWTH-2 ${ }^{\text {st }}$ GWG standards. Higher GWG in the 269 first and second trimesters, but not higher total GWG, has been previously shown to reduce the 270 risk of spontaneous preterm birth among multigravida women.[31] Other studies have also found 271 an increased risk of preterm birth associated with total GWG below the IOM guidelines.[2,24]

272 The mechanisms behind the relationships between timing and degree of inadequate GWG and 273 preterm birth require further investigation; however, it is hypothesized that inadequate GWG 274 may be a marker for macro- and micronutrient deficiencies resulting in preterm birth, particularly

275 if nutritional insults occur early in pregnancy which could affect plasma volume expansion or 276 lead to inadequate maternal tissue development to support the fetus until term.[32]

In line with findings from previous studies, we found that maternal pre-pregnancy BMI modified

279 relationships between GWG and neonatal outcomes.[2,24,30,31] Excessive GWG was positively 280 associated with the risk of stillbirth among underweight women and among normal weight 281 women using GWG z-scores. In addition, maternal overweight and obesity appeared to be 282 associated with an increased risk of perinatal mortality irrespective of GWG adequacy. To the 283 best of our knowledge, these findings are novel that have not been previously reported in the 284 context of sub-Saharan Africa. Studies using birth cohort data in Denmark, and birth and death 285 registration records in the United States, have also shown a higher risk of stillbirth and neonatal 286 mortality associated with maternal overweight and obesity.[33,34] Placental dysfunction,

287 inflammation, metabolic abnormalities, and intrapartum events are the most commonly cited 
medRxiv preprint doi: https://doi.org/10.1101/2021.08.19.21262273; this version posted August 25, 2021. The copyright holder for this preprint (which was not certified by peer review) is the author/funder, who has granted medRxiv a license to display the preprint in perpetuity.

It is made available under a CC-BY 4.0 International license .

288

289

290

291

292

293

294

295

296

297

298

299

300

301

302

303

304

305

306

307

308

309

310

mechanisms contributing to the risk of stillbirth with excessive weight.[35] However, further research is needed to understand these mechanisms and identify the contributing factors in lowincome settings.

The findings of this study should be interpreted in the context of its strength and limitations. We examined the relationships between GWG adequacy and a wide range of neonatal mortality and anthropometric outcomes using one of the largest pregnancy cohorts in sub-Saharan Africa. We used GWG adequacy ratio as the primary metric as it confers the major advantage of being independent of gestational duration. Other measures of GWG, such as total absolute weight gain (in $\mathrm{kg}$ ) and rate of weight gain ( $\mathrm{kg} /$ week), are susceptible to confounding by gestational duration and therefore were not used.[36,37] We also used the IG-GWG among normal weight women to re-examine the evidence on GWG and adverse neonatal outcomes based on a geographically diverse reference population. However, we did not have maternal weight in the preconception period and only a few participants had weight measured in the first trimester of pregnancy; as such, we used imputed weights to assess maternal pre-pregnancy BMI and GWG. Nonetheless, we previously validated the imputation method and used the most flexible approach with the smallest imputation error to ensure the validity of our findings.[14] In addition, gestational age was based on date of the last menstrual period due to the lack of ultrasound-based assessment, the gold-standard method, in low-income settings; therefore, we cannot rule out the risk of measurement error. Finally, we used secondary data from a prenatal vitamin supplementation trial conducted in HIV-negative pregnant women, which may influence the generalizability of findings at the population level. 
medRxiv preprint doi: https://doi.org/10.1101/2021.08.19.21262273; this version posted August 25, 2021. The copyright holder for this preprint (which was not certified by peer review) is the author/funder, who has granted medRxiv a license to display the preprint in perpetuity.

It is made available under a CC-BY 4.0 International license .

311 The World Health Organization Antenatal Guidelines recommend routinely monitoring weight

312 during pregnancy for optimal maternal and newborn outcomes.[38] The findings from this study

313 reaffirm the importance of optimal maternal GWG for several adverse neonatal outcomes. Most

314 women in this study gained severely inadequate or inadequate GWG which was associated with

315 poor newborn anthropometry, indicative of fetal growth restriction. In contrast, excessive GWG

316 was positively associated with large size at birth and the risk of stillbirth among underweight and

317 normal weight women. In low-income settings, multiple environmental, socio-demographic, and

318 nutritional factors may be contributing to inadequate GWG as well as adverse neonatal outcomes

$319[1,39]$. Therefore, further research is needed to identify context-specific factors for suboptimal

320 GWG and to identify interventions to mitigate inadequate or excessive GWG among women in

321 Tanzania. The findings of this study reveal that greater efforts are needed to support women to

322 achieve optimal weight pre-conceptionally and during routine antenatal care to minimize the risk

323 of adverse neonatal outcomes. 
medRxiv preprint doi: https://doi.org/10.1101/2021.08.19.21262273; this version posted August 25, 2021. The copyright holder for this preprint (which was not certified by peer review) is the author/funder, who has granted medRxiv a license to display the preprint in perpetuity.

It is made available under a CC-BY 4.0 International license .

\section{Acknowledgements}

325 We thank the mothers and children, the field teams, including nurses, midwives, supervisors, the

326 laboratory staff, the administrative staff, and all other members of the Harvard-Tanzania

327 collaboration for making this study possible.

328

329 Statement of Ethics

330 Trial protocol was approved by the Institutional Reviews Boards at the Harvard T.H Chan

331 School of Public Health and Muhimbili University of Health and Allied Sciences (MUHAS) in

332 Tanzania. Only de-identified secondary data was used in this study and therefore exempt from

333 full review by the Institutional Review Board of the Harvard T.H. Chan School of Public Health.

Conflict of Interest Statement

336 The authors have no conflicts of interest to declare.

\section{Funding Sources}

339 This study was supported in part by funding from the Bill and Melinda Gates Foundation 340 (OP1204850) and the Canadian Institutes of Health Research Fellowship to NP.

\section{$342 \quad$ Author Contributions}

343 NP and WF conceptualized and designed the study. NP carried out the analysis and data 344 interpretation, drafted the initial manuscript, and reviewed and revised the manuscript. DQ, AM,

345 MW, and EL contributed to the study design, analysis, and interpretation of the data, and

346 critically reviewed the manuscript for important intellectual content. AP and WU were 
347 investigators on the parent trial, contributed to the design and acquisition of the data, and

348 critically reviewed the manuscript for important intellectual content. WWF was the principal

349 investigator on the parent trial, contributed to the analysis and interpretation of the data, and

350 critically reviewed the manuscript for important intellectual content. All authors approved the

351 submitted manuscript.

352

353 Data Availability Statement

354 The data that support the findings of this study are not publicly available due to ethical reasons. 
medRxiv preprint doi: https://doi.org/10.1101/2021.08.19.21262273; this version posted August 25, 2021. The copyright holder for this preprint (which was not certified by peer review) is the author/funder, who has granted medRxiv a license to display the preprint in perpetuity.

It is made available under a CC-BY 4.0 International license .

\section{References}

1 Institute of Medicine, National Research Council. Weight gain during pregnancy: reexamining the guidelines. Washington, DC.: The National Academies Press; 2009.

2 Goldstein RF, Abell SK, Ranasinha S, Misso M, Boyle JA, Black MH, et al. Association of gestational weight gain with maternal and infant outcomes: A systematic review and meta-analysis. JAMA. 2017;317(21):2207-25.

3 Voerman E, Santos S, Inskip H, Amiano P, Barros H, Charles M-A, et al. Association of Gestational Weight Gain With Adverse Maternal and Infant Outcomes. JAMA. 2019;321(17):1702.

4 Christian P, Lee SE, Angel MD, Adair LS, Arifeen SE, Ashorn P, et al. Risk of childhood undernutrition related to small-for-gestational age and preterm birth in low- and middleincome countries. Int J Epidemiol. 2013;1-16.

5 Adair LS, Fall CHD, Osmond C, Stein AD, Martorell R, Ramirez-Zea M, et al. Associations of linear growth and relative weight gain during early life with adult health and human capital in countries of low and middle income: Findings from five birth cohort studies. Lancet. 2013;382(9891):525-34.

6 Perumal N, Manji KP, Darling AM, Kisenge RR, Kvestad I, Hysing M, et al. Gestational Age, Birth Weight, and Neurocognitive Development in Adolescents in Tanzania. J Pediatr. 2021

7 Stein AD, Barros FC, Bhargava SK, Hao W, Horta BL, Lee N, et al. Birth status, child growth, and adult outcomes in low- and middle-income countries. J Pediatr. 2013 Dec;163(6):1740-1746.e4.

8 Blencowe H, Krasevec J, de Onis M, Black RE, An X, Stevens GA, et al. National, regional, and worldwide estimates of low birthweight in 2015, with trends from 2000: a systematic analysis. Lancet Glob Heal. 2019;7(7):e849-60.

9 Chawanpaiboon S, Vogel JP, Moller AB, Lumbiganon P, Petzold M, Hogan D, et al. Global, regional, and national estimates of levels of preterm birth in 2014: a systematic review and modelling analysis. Lancet Glob Heal. 2019;7(1):e37-46.

10 Siega-Riz AM, Bodnar LM, Stotland NE, Stang J. The Current Understanding of Gestational Weight Gain Among Women with Obesity and the Need for Future Research. NAM Perspect. 2020;1-12.

11 Wang D, Wang M, Darling AM, Perumal N, Liu E, Danaei G, et al. Gestational weight gain in low-income and middle-income countries: A modelling analysis using nationally representative data. BMJ Glob Heal. 2020;5(11):1-9.

12 Asefa F, Cummins A, Dessie Y, Hayen A, Foureur M. Gestational weight gain and its effect on birth outcomes in sub-Saharan Africa: Systematic review and meta-analysis. PLoS One. 2020;15(4):1-23.

13 Fawzi WW, Msamanga GI, Urassa W, Hertzmark E, Petraro P, Willett WC, et al. Vitamins and perinatal outcomes among HIV-negative women in Tanzania. N Engl J Med. 2007;356:1423-31.

14 Yang J, Wang D, Darling AM, Liu E, Perumal N, Fawzi WW, et al. Methodological approaches to imputing early-pregnancy weight based on weight measures collected during pregnancy. BMC Med Res Methodol. 2021;21(1):1-10.

15 World Health Organization. BMI-for-age (5-19 years). 2021 [cited 2021 Jun 21]. Available from: https://www.who.int/tools/growth-reference-data-for-5to19- 
medRxiv preprint doi: https://doi.org/10.1101/2021.08.19.21262273; this version posted August 25, 2021. The copyright holder for this preprint (which was not certified by peer review) is the author/funder, who has granted medRxiv a license to display the preprint in perpetuity.

It is made available under a CC-BY 4.0 International license .

16 Adu-Afarwuah S, Lartey A, Okronipa H, Ashorn P, Ashorn U, Zeilani M, et al. Maternal Supplementation with Small-Quantity Lipid-Based Nutrient Supplements Compared with Multiple Micronutrients, but Not with Iron and Folic Acid, Reduces the Prevalence of Low Gestational Weight Gain in Semi-Urban Ghana: A Randomized Controlled Trial. J Nutr. 2017;147(4):697-705.

17 Ismail LC, Bishop DC, Pang R, Ohuma EO, Kac G, Abrams B, et al. Gestational weight gain standards based on women enrolled in the Fetal Growth Longitudinal Study of the INTERGROWTH-21st project: A Prospective longitudinal cohort study. BMJ. 2016;352.

18 Filmer D, Pritchett LH. Estimating wealth effects without expenditure data - Or tears: An application to educational enrollments in states of India. Demography. 2001;38(1):11532.

19 Weinberg CR. Invited Commentary: Troubling Trends in Birth Weight. Am J Epidemiol. 2016;183(1):24-5.

20 Darling AM, Werler MM, Cantonwine DE, Fawzi WW, McElrath TF. Timing and Amount of Gestational Weight Gain in Association with Adverse Birth Outcomes. Epidemiology. 2019;30(5):695-705.

21 Johnson W, Elmrayed SAA, Sosseh F, Prentice AM, Moore SE. Preconceptional and gestational weight trajectories and risk of delivering a small-for-gestational-age baby in rural Gambia. Am J Clin Nutr. 2017;105(6):1474-82.

22 Hasan SMT, Khan MA, Ahmed T. Inadequate maternal weight gain in the third trimester increases the risk of intrauterine growth restriction in rural Bangladesh. PLoS One. 2019;14(2):1-14.

23 Goldstein RF, Abell SK, Ranasinha S, Misso ML, Boyle JA, Harrison CL, et al. Gestational weight gain across continents and ethnicity: Systematic review and metaanalysis of maternal and infant outcomes in more than one million women. BMC Med. 2018;16(1):1-14.

24 Li N, Liu E, Guo J, Pan L, Li B, Wang P, et al. Maternal prepregnancy body mass index and gestational weight gain on pregnancy outcomes. PLoS One. 2013;8(12).

25 Xiao L, Ding G, Vinturache A, Xu J, Ding Y, Guo J, et al. Associations of maternal prepregnancy body mass index and gestational weight gain with birth outcomes in Shanghai, China. Sci Rep. 2017;7:1-8.

26 Adair LS, Fall CHD, Osmond C, Stein AD, Martorell R, Ramirez-Zea M, et al. Associations of linear growth and relative weight gain during early life with adult health and human capital in countries of low and middle income: findings from five birth cohort studies. Lancet. 2013 Aug;382(9891):525-34.

27 Said AS, Manji KP. Risk factors and outcomes of fetal macrosomia in a tertiary centre in Tanzania: A case-control study. BMC Pregnancy Childbirth. 2016;16(1):1-8.

28 Bauserman MS, Bann CM, Hambidge KM, Garces AL, Figueroa L, Westcott JL, et al. Gestational weight gain in 4 low- and middle-income countries and associations with birth outcomes: a secondary analysis of the Women First Trial. Am J Clin Nutr. 2021;1-9.

29 Johnson W, Elmrayed S, Sosseh F, Prentice A, Moore S. Preconceptional and gestational weight trajectories and risk of delivering a small-for-gestational-age baby in rural Gambia. Am J Clin Nutr. 2017;105(6):1474-82.

30 Kac G, Arnold CD, Matias SL, Mridha MK, Dewey KG. Gestational weight gain and newborn anthropometric outcomes in rural Bangladesh. Matern Child Nutr. 2019;15(4):1- 
medRxiv preprint doi: https://doi.org/10.1101/2021.08.19.21262273; this version posted August 25, 2021. The copyright holder for this preprint (which was not certified by peer review) is the author/funder, who has granted medRxiv a license to display the preprint in perpetuity.

It is made available under a CC-BY 4.0 International license.

11.

31 Darling AM, Werler MM, Cantonwine DE, Fawzi WW, McElrath TF. Timing and amount of GWG in association with adverse birth outcomes. Epidemiology. 2019;30:695-705.

32 Carmichael SL, Abrams B. A critical review of the relationship between GWG and preterm delivery. Obstet Gynecol. 1997;88(5).

33 Nohr EA, Wolff S, Kirkegaard H, Wu C, Andersen AMN, Olsen J, et al. Cause-specific stillbirth and neonatal death according to prepregnancy obesity and early gestational weight gain: A study in the Danish national birth cohort. Nutrients. 2021;13(5).

34 Yu YH, Bodnar LM, Himes KP, Brooks MM, Naimi AI. Association of Overweight and Obesity Development Between Pregnancies With Stillbirth and Infant Mortality in a Cohort of Multiparous Women. Obstet Gynecol. 2020;135(3):634-43.

35 Woolner AMF, Bhattacharya S. Obesity and stillbirth. Best Pract Res Clin Obstet Gynaecol. 2015;29(3):415-26.

36 Hutcheon JA, Bodnar LM. Good Practices for Observational Studies of Maternal Weight and Weight Gain in Pregnancy. Paediatr Perinat Epidemiol. 2018;152-60.

37 Bodnar LM, Hutcheon JA, Parisi SM, Pugh SJ, Abrams B. Comparison of gestational weight gain z-scores and traditional weight gain measures in relation to perinatal outcomes. Paediatr Perinat Epidemiol. 2015;29(1):11-21.

38 World Health Organization. WHO recommendations on antenatal care for a positive pregnancy experience. Geneva; 2016.

39 King JC. A summary of pathways or mechanisms linking preconception maternal nutrition with birth outcomes. J Nutr. 2016;146(7):1437S-1444S. 
medRxiv preprint doi: https://doi.org/10.1101/2021.08.19.21262273; this version posted August 25, 2021. The copyright holder for this preprint (which was not certified by peer review) is the author/funder, who has granted medRxiv a license to display the preprint in perpetuity.

It is made available under a CC-BY 4.0 International license .

\section{FIGURE LEGENDS}

Figure 1: Conceptual framework for the association between maternal gestational weight gain and perinatal outcomes.

Figure 2: Relationship between total percent adequacy of gestational weight gain, based on Institute of Medicine recommendations, and risk of adverse neonatal outcomes, disaggregated by maternal pre-pregnancy body mass index (BMI) of underweight $(<18.5 \mathrm{~kg} / \mathrm{m} 3)$, normal weight $(18.5-24.9 \mathrm{~kg} / \mathrm{m} 2)$, and overweight or obese $(\geq 25 \mathrm{~kg} / \mathrm{m} 2)$. An asterisk marks statistically significant $(\mathrm{P}<0.05)$ difference in the relationship between adequacy of gestational weight gain and neonatal outcome among women who were underweight or overweight (compared to normal weight) at the start of pregnancy. 
medRxiv preprint doi: https://doi.org/10.1101/2021.08.19.21262273; this version posted August 25, 2021. The copyright holder for this preprint (which was not certified by peer review) is the author/funder, who has granted medRxiv a license to display the preprint in perpetuity.

It is made available under a CC-BY 4.0 International license.

Table 1: Institute of Medicine guidelines for expected weight gain and rate of weight gain based on maternal pre-pregnancy body mass index (BMI) classification.

\begin{tabular}{lcc} 
BMI classifications & $\begin{array}{c}\text { Expected 1st } \\
\text { trimester weight } \\
\left(\mathbf{1 3}^{\mathbf{6} / 7} \text { weeks) }\right.\end{array}$ & $\begin{array}{c}\text { Recommended rate of } \\
\text { weight gain in 2 } \\
\mathbf{3}^{\text {rd }} \text { trimester }\end{array}$ \\
\hline Underweight $\left(<18.5 \mathrm{~kg} / \mathrm{m}^{2}\right)$ & $2 \mathrm{~kg}$ & $0.51 \mathrm{~kg} /$ week \\
Normal weight $\left(18.5 \mathrm{to} 24.9 \mathrm{~kg} / \mathrm{m}^{2}\right)$ & $1 \mathrm{~kg}$ & $0.42 \mathrm{~kg} /$ week \\
Overweight $\left(25\right.$ to $\left.29.9 \mathrm{~kg} / \mathrm{m}^{2}\right)$ & $0.5 \mathrm{~kg}$ & $0.28 \mathrm{~kg} /$ week \\
Obese $\left(\geq 30 \mathrm{~kg} / \mathrm{m}^{2}\right)$ & $0.5 \mathrm{~kg}$ & $0.22 \mathrm{~kg} /$ week \\
\hline
\end{tabular}


medRxiv preprint doi: https://doi.org/10.1101/2021.08.19.21262273; this version posted August 25, 2021. The copyright holder for this preprint (which was not certified by peer review) is the author/funder, who has granted medRxiv a license to display the preprint in perpetuity.

It is made available under a CC-BY 4.0 International license .

Table 2: Participant characteristics for women in the Prenatal Vitamins Trial.

\begin{tabular}{|c|c|c|c|c|c|c|}
\hline \multirow[b]{2}{*}{ Characteristic } & \multirow[b]{2}{*}{$\begin{array}{c}\text { Overall } \\
(\mathrm{n}=7561)\end{array}$} & \multicolumn{4}{|c|}{ Gestational weight gain adequacy } & \multirow[b]{2}{*}{$P^{1}$} \\
\hline & & $\begin{array}{c}\text { Severely } \\
\text { inadequate } \\
(<70 \%) \\
(n=1928)\end{array}$ & $\begin{array}{c}\text { Inadequate } \\
\text { (70 to <90\%) } \\
(n=1938)\end{array}$ & $\begin{array}{c}\text { Adequate } \\
(90 \text { to }<125 \%) \\
(n=2315)\end{array}$ & $\begin{array}{c}\text { Excessive } \\
(\geq 125 \%) \\
(n=1392)\end{array}$ & \\
\hline \multicolumn{7}{|l|}{ Maternal age ${ }^{2}$, yrs } \\
\hline$<20$ & $1216(16)$ & $368(19)$ & $313(16)$ & $371(16)$ & $164(12)$ & $<0.001$ \\
\hline $20-24$ & $3002(40)$ & $793(42)$ & $823(43)$ & $890(39)$ & $496(36)$ & \\
\hline $25-29$ & 2027 (27) & $441(23)$ & $489(25)$ & $652(28)$ & $445(32)$ & \\
\hline$\geq 30$ & $1279(17)$ & $305(16)$ & $300(16)$ & $388(17)$ & $286(21)$ & \\
\hline \multicolumn{7}{|l|}{ Education ${ }^{3}$, yrs } \\
\hline 0 to $4 \mathrm{yrs}$ & $841(11)$ & $251(13)$ & $253(13)$ & $221(9.60)$ & $116(8.34)$ & $<0.001$ \\
\hline 5 to 7 yrs & $5009(67)$ & $1344(70)$ & $1283(67)$ & $1519(66)$ & $863(62)$ & \\
\hline 8 to 11 yrs & $1288(17)$ & $249(13)$ & $315(16)$ & $428(19)$ & $296(21)$ & \\
\hline $12+y r s$ & $388(5.2)$ & 64 (3.35) & 75 (3.89) & $133(5.78)$ & $116(8.34)$ & \\
\hline Married or living with partner ${ }^{4}$ & $6632(88)$ & $1674(88)$ & $1700(89)$ & $2025(88)$ & $1233(89)$ & 0.97 \\
\hline \multicolumn{7}{|l|}{ Prior pregnancies ${ }^{5}$} \\
\hline None & $3452(46)$ & $901(47)$ & $891(46)$ & $1066(46)$ & $588(42)$ & 0.002 \\
\hline 1 & $2088(28)$ & $507(27)$ & $535(28)$ & $662(29)$ & $380(27)$ & \\
\hline 2 & 1099 (15) & $254(13)$ & $271(14)$ & $316(14)$ & $256(18)$ & \\
\hline$\geq 3$ & $893(12)$ & $241(13)$ & $229(12)$ & $257(11)$ & $166(12)$ & \\
\hline \multicolumn{7}{|l|}{ Supplementation group } \\
\hline Placebo & $3772(50)$ & $1005(53)$ & $965(50)$ & $1131(49)$ & $671(48)$ & 0.04 \\
\hline MMS & $3789(50)$ & $909(47)$ & $969(50)$ & $1184(51)$ & $727(52)$ & \\
\hline \multicolumn{7}{|l|}{ Wealth quartile, $\mathrm{n}(\%)^{6}$} \\
\hline $1^{\text {st }}$ (lowest) & 2964 (39) & $894(47)$ & $792(41)$ & $834(36)$ & $444(32)$ & $<0.001$ \\
\hline $2^{\text {nd }}$ & $1045(14)$ & $293(15)$ & $282(15)$ & $306(13)$ & $164(12)$ & \\
\hline $3^{\text {rd }}$ & $2109(28)$ & $478(25)$ & $539(28)$ & $682(30)$ & $410(29)$ & \\
\hline $4^{\text {th }}$ (highest) & $1420(19)$ & $244(13)$ & $315(16)$ & $487(21)$ & $374(27)$ & \\
\hline \multicolumn{7}{|l|}{ Maternal pre-pregnancy BMI, n (\%) } \\
\hline Underweight $\left(<18.5 \mathrm{~kg} / \mathrm{m}^{2}\right)$ & $797(11)$ & $285(15)$ & $292(15)$ & $182(7.86)$ & $38(2.72)$ & $<0.001$ \\
\hline Normal weight $\left(18.5-24.9 \mathrm{~kg} / \mathrm{m}^{2}\right)$ & $4962(66)$ & $1390(73)$ & $1477(76)$ & $1698(73)$ & $397(28)$ & \\
\hline Overweight $\left(25-29.9 \mathrm{~kg} / \mathrm{m}^{2}\right)$ & $1423(19)$ & $193(10)$ & $141(7.29)$ & $383(17)$ & $706(51)$ & \\
\hline Obese $\left(\geq 30 \mathrm{~kg} / \mathrm{m}^{2}\right)$ & $379(5.01)$ & $46(2.40)$ & $24(1.24)$ & $52(2.25)$ & $257(18)$ & \\
\hline \multicolumn{7}{|l|}{ Maternal height } \\
\hline Height $<155 \mathrm{~cm}$ & $3439(45)$ & $954(50)$ & $910(47)$ & $990(43)$ & $585(42)$ & $<0.001$ \\
\hline \multirow{2}{*}{\multicolumn{7}{|c|}{ Maternal alcohol consumption, $\mathrm{n}(\%)^{\prime}$}} \\
\hline & & & & & & \\
\hline Never & $6584(87)$ & $1688(88)$ & $1712(89)$ & $2011(87)$ & $1173(84)$ & 0.002 \\
\hline Less than once per week & $712(9.45)$ & $173(9.05)$ & $150(7.80)$ & $221(9.57)$ & $168(12)$ & \\
\hline Once or more times per week & $238(3.16)$ & $50(2.62)$ & $62(3.22)$ & $78(3.38)$ & $48(3.46)$ & \\
\hline Maternal malaria infection ${ }^{\circ}, \mathrm{n}(\%)$ & $111(1.5)$ & $35(1.92)$ & $27(1.46)$ & $31(1.40)$ & $18(1.35)$ & 0.49 \\
\hline \multicolumn{7}{|l|}{ Maternal reproductive history ${ }^{9}$} \\
\hline Previous abortions or miscarriages, $\mathrm{n}(\%)$ & $1108(16)$ & $256(15)$ & $265(15)$ & $340(16)$ & $247(19)$ & 0.008 \\
\hline Previous stillbirth, n (\%) & $221(3.30)$ & $55(3.30)$ & $53(3.08)$ & $61(2.96)$ & $52(4.17)$ & 0.27 \\
\hline Previous fetal loss, n (\%) & $1296(17)$ & $303(16)$ & $310(16)$ & $394(17)$ & $289(21)$ & 0.001 \\
\hline
\end{tabular}


medRxiv preprint doi: https://doi.org/10.1101/2021.08.19.21262273; this version posted August 25, 2021. The copyright holder for this preprint (which was not certified by peer review) is the author/funder, who has granted medRxiv a license to display the preprint in perpetuity.

It is made available under a CC-BY 4.0 International license.

Table 3: Associations between percent adequacy of gestational weight gain (GWG) compared to the Institute of Medicine 2009 recommendations and neonatal outcomes'.

\begin{tabular}{|c|c|c|c|c|c|c|}
\hline Characteristic & $\begin{array}{c}\text { Total } \\
\mathbf{n}\end{array}$ & $\begin{array}{c}\text { No. of } \\
\text { cases (\%) }\end{array}$ & $\begin{array}{c}\text { Severely } \\
\text { Inadequate }(<70 \%) \\
\operatorname{RR}(95 \% \mathrm{Cl})\end{array}$ & $\begin{array}{c}\text { Inadequate } \\
\text { (70\% to <90\%) } \\
\text { RR }(95 \% \mathrm{Cl})\end{array}$ & $\begin{array}{c}\text { Adequate } \\
\text { (90\% to 125\%) } \\
\text { Reference }\end{array}$ & $\begin{array}{c}\text { Excessive } \\
(>125 \%) \\
\operatorname{RR}(95 \% \mathrm{Cl})\end{array}$ \\
\hline \multicolumn{7}{|l|}{ Total GWG } \\
\hline Stillbirth & 6578 & 209 (3.18) & $1.16(0.79,1.71)$ & $0.97(0.64,1.46)$ & 1.0 & $1.60(1.03,2.42)$ \\
\hline Perinatal death & 6375 & $350(5.49)$ & $1.04(0.77,1.40)$ & $0.85(0.62,1.17)$ & 1.0 & $1.23(0.89,1.69)$ \\
\hline Preterm-born & 6370 & $901(14.2)$ & $1.12(0.93,1.36)$ & $1.00(0.83,1.22)$ & 1.0 & $1.23(0.97,1.56)$ \\
\hline Low birthweight & 6205 & $381(6.14)$ & $1.64(1.24,2.16)$ & $1.17(0.87,1.57)$ & 1.0 & $1.30(0.89,1.89)$ \\
\hline Small-for-gestational age & 6188 & $1248(20)$ & $1.81(1.53,2.14)$ & $1.47(1.24,1.75)$ & 1.0 & $0.85(0.67,1.07)$ \\
\hline Large-for-gestational age & 6188 & $765(12.4)$ & $0.69(0.56,0.86)$ & $0.76(0.61,0.93)$ & 1.0 & $1.44(1.14,1.81)$ \\
\hline Stunting at birth & 4590 & $1226(27)$ & $1.27(1.06,1.52)$ & $1.20(1.00,1.43)$ & 1.0 & $0.97(0.78,1.20)$ \\
\hline Microcephaly & 5435 & $472(8.69)$ & $1.35(1.04,1.74)$ & $1.32(1.02,1.71)$ & 1.0 & $0.91(0.65,1.26)$ \\
\hline Macrosomia & 6205 & $160(2.58)$ & $0.29(0.16,0.54)$ & $0.65(0.41,1.03)$ & 1.0 & $1.52(1.00,2.31)$ \\
\hline \multicolumn{7}{|l|}{ Early GWG ( $2^{\text {nd }}$ trimester) } \\
\hline Stillbirth & 7054 & $247(3.50)$ & $1.05(0.70,1.57)$ & $1.02(0.72,1.46)$ & 1.0 & $1.24(0.83,1.86)$ \\
\hline Perinatal death & 6750 & $407(6.03)$ & $1.04(0.76,1.42)$ & $0.89(0.67,1.19)$ & 1.0 & $1.06(0.77,1.46)$ \\
\hline Preterm-born & 6807 & $1075(16)$ & $1.58(1.31,1.91)$ & $0.89(0.75,1.07)$ & 1.0 & $0.99(0.79,1.24)$ \\
\hline Low birthweight & 6579 & $448(6.81)$ & $1.67(1.27,2.21)$ & $1.17(0.90,1.51)$ & 1.0 & $1.09(0.77,1.55)$ \\
\hline Small-for-gestational age & 6559 & $1310(20)$ & $1.27(1.06,1.53)$ & $1.36(1.16,1.60)$ & 1.0 & $0.86(0.70,1.07)$ \\
\hline Large-for-gestational age & 6559 & $874(13.3)$ & $1.22(0.99,1.51)$ & $0.78(0.63,0.95)$ & 1.0 & $1.19(0.95,1.50)$ \\
\hline Stunting at birth & 4741 & $1256(26)$ & $0.99(0.81,1.21)$ & $1.05(0.89,1.25)$ & 1.0 & $1.08(0.88,1.33)$ \\
\hline Microcephaly & 5615 & $479(8.53)$ & $1.02(0.76,1.35)$ & $1.01(0.79,1.29)$ & 1.0 & $1.02(0.75,1.38)$ \\
\hline Macrosomia & 6579 & $166(2.52)$ & $0.42(0.21,0.81)$ & $0.63(0.38,1.02)$ & 1.0 & $1.98(1.27,3.08)$ \\
\hline
\end{tabular}


medRxiv preprint doi: https://doi.org/10.1101/2021.08.19.21262273; this version posted August 25, 2021. The copyright holder for this preprint (which was not certified by peer review) is the author/funder, who has granted medRxiv a license to display the preprint in perpetuity.

It is made available under a CC-BY 4.0 International license.

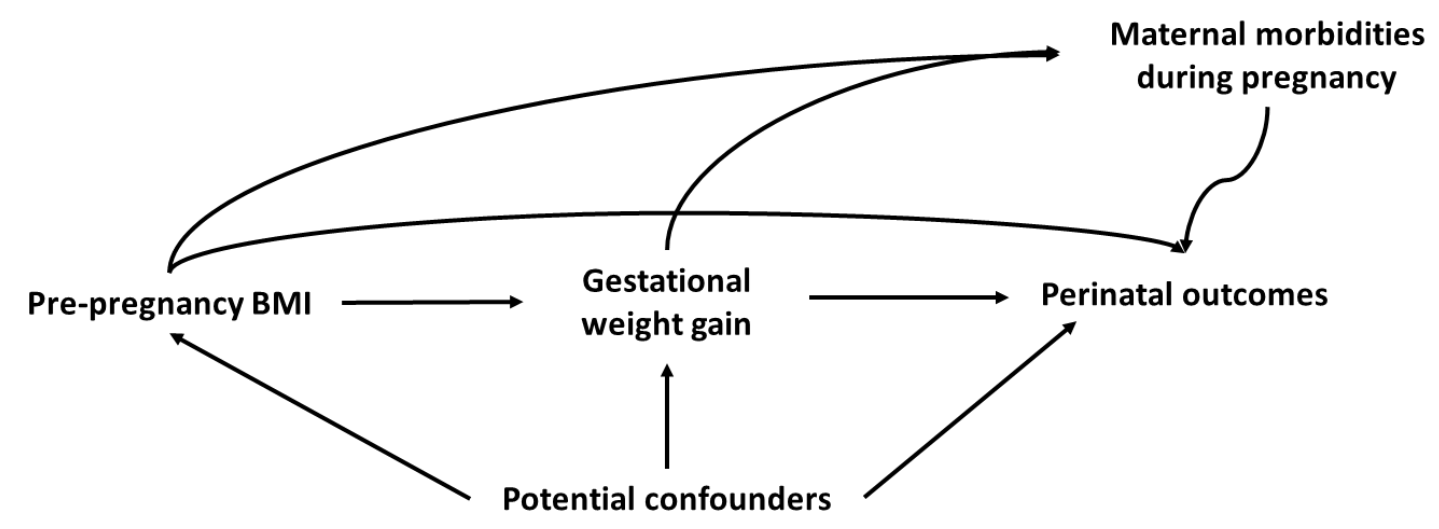



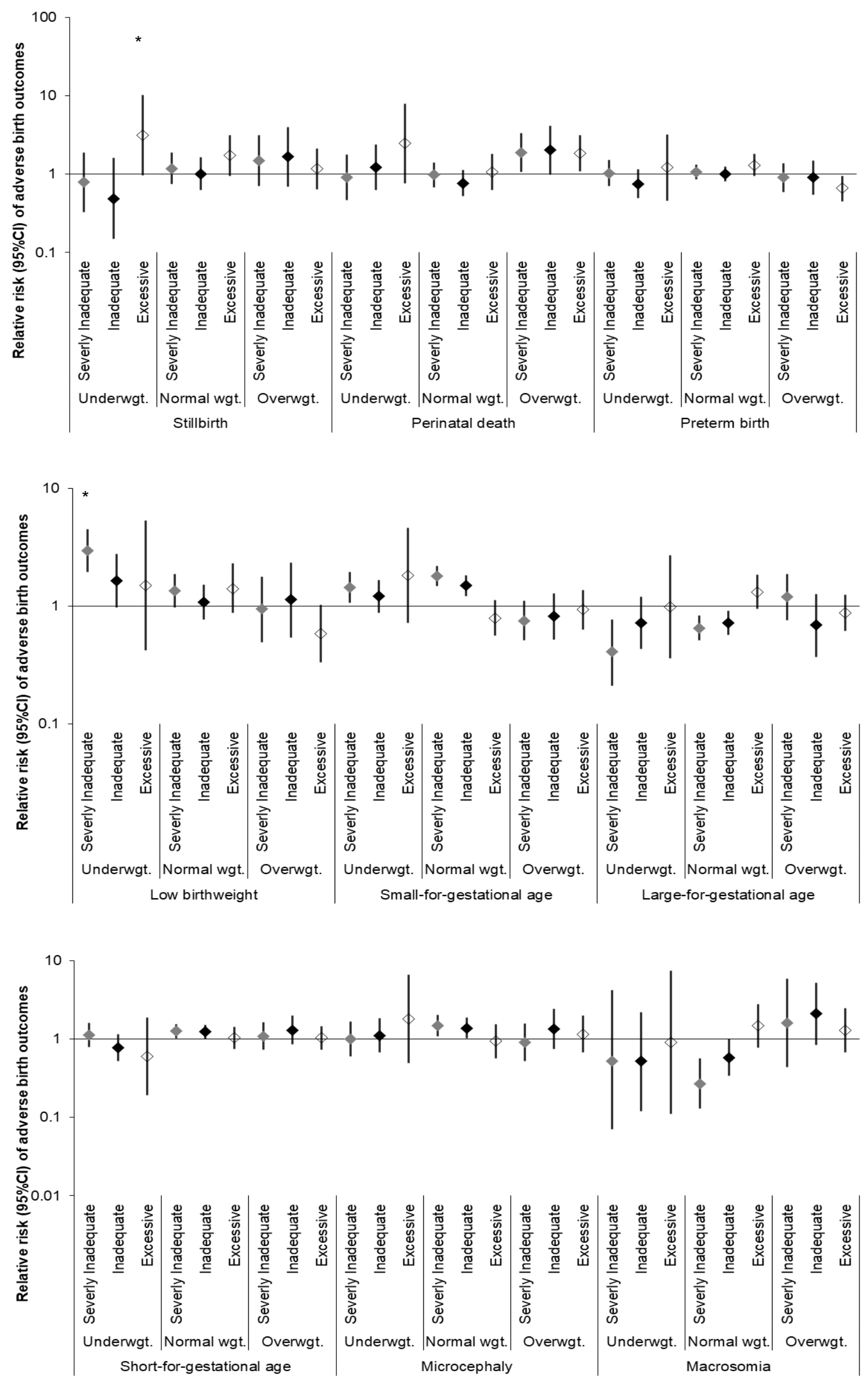